\title{
Trends in Pluviometric Precipitation and Climatic Water Balance in the hydrographic region of Paraguaçu - BA
}

\author{
Tendência da Precipitação Pluviométrica e do Balanço Hídrico Climatológico na região \\ hidrográfica do Paraguaçu - BA
}

\author{
Tailan Santos de Souza \\ Engenheiro Civil, Mestre em Engenharia Civil e Ambiental, UEFS, Brasil \\ tailan santoss@hotmail.com \\ Patricia dos Santos Nascimento \\ Engenheira Agrônoma, Doutora em Agronomia, UNESP \\ Professora Adjunta do Departamento de Tecnologia, UEFS, Brasil \\ psnascimento@uefs.br
}

\begin{abstract}
Trend analysis of hydroclimatic data is essential in the development of water resources management, as it can envisage changes in the pattern of behaviour, helping develop strategies for adaptation in the face of imminent climate change. This study aimed to investigate possible annual and seasonal trends in rainfall and climatological water balance in the hydrographic region of Paraguaçu - BA. From the historical series of precipitation, deficiency and water surpluses, between 1989 and 2018, two analysis scenarios were conducted: the first to verify the annual and seasonal trends of each station, using the traditional MannKendall (MK) methods and Sen's estimator; and the second for each sub-region of Paraguaçu, by comparing MK with the Innovative Trend Analysis (ITA). The results of the annual series, regardless of the methodology adopted, point to negative trends in rainfall, positive trends in deficit and negative trends in water surplus. Seasonally, in the autumn and winter seasons, generally considered to be drought, there were more trends of increasing rainfall and decreasing water deficiency. A comparison between the MK and ITA models showed that both have similar results for indicating trends in the sub-regions of Paraguaçu. However, the ITA has shown a higher number of significant trends.
\end{abstract}

Keywords: Water Deficit; Water Surplus; Significant Trends; Mann-Kendall; Innovative Trend Analysis.

\section{Resumo}

Em dados hidroclimáticos, a análise de tendências é essencial no desenvolvimento da gestão dos recursos hídricos, pois ela pode visionar mudanças no padrão de comportamento, auxiliando na elaboração de estratégias para adaptação diante das mudanças climáticas eminentes. Esse estudo objetivou a averiguação da presença de possíveis tendências anuais e sazonais da precipitação pluviométrica e do balanço hídrico climatológico na região hidrográfica do Paraguaçu - BA. A partir das séries históricas de precipitação, deficiência e excedentes hídricos, compreendidas entre 1989 e 2018, foram conduzidos dois cenários de análise: o primeiro para verificação das tendências anuais e sazonais de cada posto, através dos métodos tradicionais de Mann-Kendall (MK) e do estimador de Sen; e o segundo para cada sub-região do Paraguaçu, através da comparação de MK com a Análise de Tendência Inovadora (ATI). Os resultados das séries anuais, independente da metodologia adotada, apontam para tendências negativas na precipitação pluviométrica, positivas no déficit e negativas no excedente hídrico. Sazonalmente, nas estações do outono e do inverno, consideradas secas de maneira geral, ocorreram mais tendências de crescimento das chuvas e de decrescimento da deficiência hídrica. Comparando-se os modelos de MK e ATI, foi constatado que os mesmos apresentam resultados semelhantes para indicação das tendências nas sub-regiões do Paraguaçu, embora a ATI tenha apresentado uma quantidade superior de tendências significativas.

Palavras-chave: Déficit Hídrico; Excedente Hídrico; Tendências Significativas; Mann-Kendall; Análise de Tendência Inovadora. 


\section{INTRODUCTION}

Global warming has been identified as a potential agent of environmental and climatological changes. The intensification of the increase in the average temperature on the planet is responsible for considerable changes in the hydrological cycle, ranging from the recurrence of extreme weather events to the acceleration of plant metabolism (WANG et al., 2016; MOHAMMADI et al., 2017; PRĂVĂLIE et al., 2019). Thus, the scenarios of climatic variability are progressively accentuated, being represented through great contrasts between dry and humid periods and the occurrence of phenomena with less predictability (GIORGI; RAFFAELE; COPPOLA, 2019).

In this sense, trend analysis applied to time series has been a useful tool in understanding climate change and its effects on the environment and humans (PHUONG et al., 2019; ALIFUJIANG et al., 2020). This inspection of historical climatic data is intended to investigate past events to design future scenarios, signalling possible changes (PAUL et al., 2017). The trend analysis provides a good overview of the behaviour of climatic variables over time (TEHRANI; SAHOUR; BOOIJ, 2019). Trends in rainfall and water balance can affect water availability, which is vital for carrying out human activities (ANAND et al., 2018; PRĂVĂLIE et al., 2019).

The good interpretation of trends in hydrological parameter patterns can play an essential role in developing and managing water resources, especially when significant trends are detected (THOMAS; PRASANNAKUMAR, 2016; TOSUNOGLU; KISI, 2016). Furthermore, within the scope of the hydrographic region, proper planning values good adaptation and mitigation strategies in the face of climate change and the optimal use of water resources (CHANDNIHA et al., 2017; ASFAW et al., 2018; KHAN et al., 2019; ALIFUJIANG et al., 2020).

This type of management is necessary within the limits of the Paraguaçu region since the recurrence of water deficits and the poor distribution of water surpluses can exacerbate water access problems (SOUZA; NASCIMENTO, 2020). In addition, the report of the Intergovernmental Panel on Climate Change (IPCC, 2021) has reliable projections of the increase in the severity of the drought in the Brazilian Northeast, while Tavares, Arruda and Silva (2019) already indicate that the phenomenon of desertification compromises a large part of the semi-arid region. These reasons enhance the occurrence of water deficits.

According to Şen (2017) and Mrad et al., (2018), over the past three decades, trend research in hydroclimatic data has largely been based on the classical analysis of Mann-Kendall (MK) (MANN, 1945; KENDALL, 1975) in conjunction with Sen's slope test (SEN, 1968). Both methods can be applied to historical series of different categories of climatic parameters. Asfaw et al. (2018) investigated the trend of precipitation and temperature in Ethiopia. Ali et al. (2019) 
addressed long-term flows, while Wang et al. (2019) prioritised the reference evapotranspiration in China. Prăvălie et al. (2019) emphasised the trends affecting Romania's Climatic Water Balance $(C W B)$ series. Trend assessments can still cover drought rates such as the Standardised Precipitation Index (SPI) (AZAM et al., 2018) and even historical wave height series (AYDOĞAN; AYAT, 2018).

One of the limitations of these classic tests is to evaluate the series in a monotonic way, without considering the intrinsic trends in the low, medium, and high-value data (CALOIERO; COSCARELLI; FERRARI, 2018; MALIK et al., 2019). To that end, Şen (2012) developed the Innovative Trend Analysis (ITA), which has some other advantages over traditional methods and has been successfully used in recent geoscience studies (KISI, 2015; CUI et al., 2017; WU; QUIAN, 2017; ZHOU et al., 2018; ALI et al., 2019; ALIFUJIANG et al., 2020; WANG et al., 2020). However, the application of the young ITA method still needs improvement, with many points of development and discussion within the academic community (TOSUNOGLU; KISI, 2016).

Considering the above, the present study aims to ascertain the presence of possible annual and seasonal trends in rainfall and climatological water balance in the hydrographic region of Paraguaçu, in Brazil, through the spatial analysis of the magnitudes and significance of trend and the comparison between the classic Mann-Kendall method and the Innovative Trend Analysis.

\section{METHODOLOGY}

\subsection{Study Area}

The hydrographic region of Paraguaçu ( $13^{\circ} 36^{\prime} \mathrm{S}$ to $11^{\circ} 17^{\prime} \mathrm{S}, 42^{\circ} 2^{\prime} \mathrm{W}$ to $38^{\circ} 55^{\prime} \mathrm{W}$ ) has an area of $54322 \mathrm{~km}^{2}$, featuring the most important river system in the state of Bahia, Northeast of Brazil, and is comprising 86 municipalities, including Feira de Santana, the second largest in the state, in terms of population. The Paraguaçu River, the region's main watercourse, is the source responsible for the water supply of much of the capital Salvador and its metropolitan region (SILVA et al., 2017). Figure 1 shows the location of the region, its three sub-basins, location of the main rivers, the variation in altitude and the location of the pluviometric and climatic seasons considered in this study. 


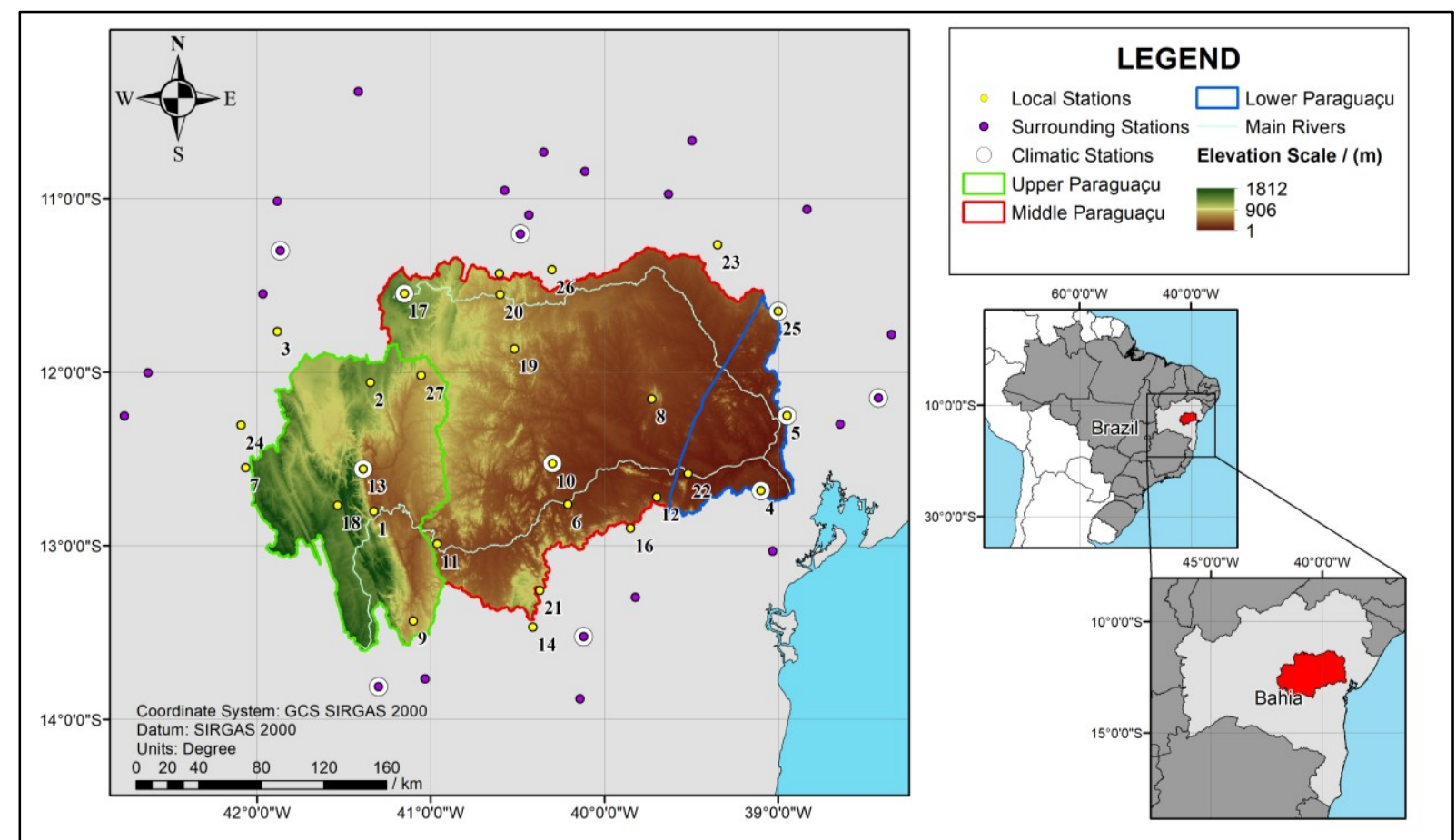

Figure 1 - Location, sub-basins, hydrography, and elevation scale of the study area, identifying the pluviometric and climatic stations.

Source: INPE, 2008; INEMA, 2014. Organised by the authors, 2021.

The upper Paraguaçu is the geographical division of higher altitudes. The dry sub-humid climate prevails, with rainy events exceeding $1000 \mathrm{~mm}$ per year. The middle Paraguaçu is characterised by a semi-arid climate, characteristic of the entire hydrographic region, with annual rainfall rates around $650 \mathrm{~mm}$. Finally, the lower Paraguaçu is the division closest to the coast. The humid to sub-humid climate predominates, with points reaching $1250 \mathrm{~mm}$ of annual rain. The average temperature in the region exceeds $25^{\circ} \mathrm{C}$, except for some mesothermal islands in Chapada Diamantina, due to the orographic effects (MACEDO, 2013).

\subsection{Dataset}

The climatological records were collected monthly from 1989 to 2018, a total of 30 years. The 50 points identified as pluviometric stations present precipitation data collected on the "Hidroweb" platform of the National Water Agency $(A N A)$. Among them, 27 are local stations referring to the points effectively inserted in the limit of the hydrographic region of Paraguaçu (Table 1). At the same time, the remaining 23 are points around the hydrographic region, which served only for spatial interpolation.

The 11 points signalled on the map as climatic stations, rainfall data, and present temperature data used in the calculation of the CWB, collected in the Meteorological Database for Teaching and Research (BDMEP) of the National Institute of Meteorology (INMET). Based on these temperature series, the other locations in this study had their monthly averages estimated from 
Inverse Distance Weighting (IDW) interpolation model. This deterministic model has the best temperature modelling performance for a relatively low density of climatic seasons (HADI; TOMBUL, 2018).

Table 1 - Data from the 27 stations situated within the hydrographic region of Paraguaçu.

\begin{tabular}{|c|c|c|c|c|c|}
\hline ID & Municipality & $\begin{array}{l}\text { Altitude } \\
\text { / (m) }\end{array}$ & $\begin{array}{l}\text { Average Annual } \\
\text { Rainfall / (mm) }\end{array}$ & Latitude & Longitude \\
\hline 1 & Andaraí & 330 & 977 & $12^{\circ} 48^{\prime} 06^{\prime \prime} \mathrm{S}$ & $41^{\circ} 19^{\prime} 39^{\prime \prime} \mathrm{W}$ \\
\hline 2 & Bonito & 962 & 961 & $12^{\circ} 03^{\prime} 36^{\prime \prime} \mathrm{S}$ & $41^{\circ} 20^{\prime} 51^{\prime \prime} \mathrm{W}$ \\
\hline 3 & Canarana & 693 & 420 & $11^{\circ} 46^{\prime} 00^{\prime \prime} \mathrm{S}$ & $41^{\circ} 53^{\prime} 00^{\prime \prime} \mathrm{W}$ \\
\hline 4 & Cruz das Almas & 226 & 1079 & $12^{\circ} 41^{\prime} 00^{\prime \prime} \mathrm{S}$ & $39^{\circ} 06^{\prime} 00^{\prime \prime} \mathrm{W}$ \\
\hline 5 & Feira de Santana & 231 & 647 & $12^{\circ} 15^{\prime} 00^{\prime \prime} \mathrm{S}$ & $38^{\circ} 57^{\prime} 00^{\prime \prime} \mathrm{W}$ \\
\hline 6 & Iaçu & 237 & 518 & $12^{\circ} 45^{\prime} 44^{\prime \prime} \mathrm{S}$ & $40^{\circ} 12^{\prime} 39^{\prime \prime} \mathrm{W}$ \\
\hline 7 & Ibitiara & 1098 & 681 & $12^{\circ} 33^{\prime} 00^{\prime \prime} \mathrm{S}$ & $42^{\circ} 04^{\prime} 00^{\prime \prime} \mathrm{W}$ \\
\hline 8 & Ipirá & 350 & 754 & $12^{\circ} 09^{\prime} 16^{\prime \prime} \mathrm{S}$ & $39^{\circ} 43^{\prime} 38^{\prime \prime} \mathrm{W}$ \\
\hline 9 & Iramaia & 590 & 443 & $13^{\circ} 26^{\prime} 00^{\prime \prime} \mathrm{S}$ & $41^{\circ} 06^{\prime} 00^{\prime \prime} \mathrm{W}$ \\
\hline 10 & Itaberaba & 250 & 620 & $12^{\circ} 31^{\prime} 36^{\prime \prime} \mathrm{S}$ & $40^{\circ} 17^{\prime} 59^{\prime \prime} \mathrm{W}$ \\
\hline 11 & Itaetê & 299 & 621 & $12^{\circ} 59^{\prime} 24^{\prime \prime} \mathrm{S}$ & $40^{\circ} 57^{\prime} 48^{\prime \prime} \mathrm{W}$ \\
\hline 12 & Itatim & 260 & 375 & $12^{\circ} 43^{\prime} 10^{\prime \prime} \mathrm{S}$ & $39^{\circ} 41^{\prime} 57^{\prime \prime} \mathrm{W}$ \\
\hline 13 & Lençóis & 439 & 1018 & $12^{\circ} 33^{\prime} 26^{\prime \prime} \mathrm{S}$ & $41^{\circ} 23^{\prime} 19^{\prime \prime} \mathrm{W}$ \\
\hline 14 & Maracás & 677 & 547 & $13^{\circ} 28^{\prime} 08^{\prime \prime} \mathrm{S}$ & $40^{\circ} 24^{\prime} 44^{\prime \prime} \mathrm{W}$ \\
\hline 15 & Miguel Calmon & 562 & 605 & $11^{\circ} 25^{\prime} 57^{\prime \prime} \mathrm{S}$ & $40^{\circ} 36^{\prime} 16^{\prime \prime} \mathrm{W}$ \\
\hline 16 & Milagres & 395 & 490 & $12^{\circ} 54^{\prime} 00^{\prime \prime} \mathrm{S}$ & $39^{\circ} 51^{\prime} 00^{\prime \prime} \mathrm{W}$ \\
\hline 17 & Morro do Chapéu & 1003 & 639 & $11^{\circ} 32^{\prime} 51^{\prime \prime} \mathrm{S}$ & $41^{\circ} 09^{\prime} 05^{\prime \prime} \mathrm{W}$ \\
\hline 18 & Mucugê & 219 & 1087 & $12^{\circ} 45^{\prime} 59^{\prime \prime} \mathrm{S}$ & $41^{\circ} 32^{\prime} 10^{\prime \prime} \mathrm{W}$ \\
\hline 19 & Mundo Novo & 515 & 873 & $11^{\circ} 51^{\prime} 56^{\prime \prime} \mathrm{S}$ & $40^{\circ} 31^{\prime} 04^{\prime \prime} \mathrm{W}$ \\
\hline 20 & Piritiba & 508 & 624 & $11^{\circ} 33^{\prime} 12^{\prime \prime} \mathrm{S}$ & $40^{\circ} 36^{\prime} 00^{\prime \prime} \mathrm{W}$ \\
\hline 21 & Planaltino & 723 & 660 & $13^{\circ} 15^{\prime} 27^{\prime \prime} \mathrm{S}$ & $40^{\circ} 22^{\prime} 21^{\prime \prime} \mathrm{W}$ \\
\hline 22 & Rafael Jambeiro & 159 & 582 & $12^{\circ} 35^{\prime} 06^{\prime \prime} \mathrm{S}$ & $39^{\circ} 31^{\prime} 06^{\prime \prime} \mathrm{W}$ \\
\hline 23 & Santaluz & 349 & 384 & $11^{\circ} 16^{\prime} 00^{\prime \prime} \mathrm{S}$ & $39^{\circ} 21^{\prime} 00^{\prime \prime} \mathrm{W}$ \\
\hline 24 & Seabra & 1033 & 485 & $12^{\circ} 18^{\prime} 22^{\prime \prime} \mathrm{S}$ & $42^{\circ} 05^{\prime} 31^{\prime \prime} \mathrm{W}$ \\
\hline 25 & Serrinha & 360 & 717 & $11^{\circ} 39^{\prime} 00^{\prime \prime} \mathrm{S}$ & $39^{\circ} 00^{\prime} 00^{\prime \prime} \mathrm{W}$ \\
\hline 26 & Serrolândia & 380 & 670 & $11^{\circ} 24^{\prime} 38^{\prime \prime} \mathrm{S}$ & $40^{\circ} 18^{\prime} 13^{\prime \prime} \mathrm{W}$ \\
\hline 27 & Utinga & 511 & 683 & $12^{\circ} 01^{\prime} 10^{\prime \prime} \mathrm{S}$ & $41^{\circ} 03^{\prime} 17^{\prime \prime} \mathrm{W}$ \\
\hline
\end{tabular}

Source: ANA, 2019. Organised by the authors, 2021.

The filling of gaps in the monthly historical series was carried out with the help of the kriging geostatistical interpolator, which considers the spatial correlation and reproduces good estimates (MEDEIROS et al., 2019; BRUBACHER; OLIVEIRA; GUASSELI, 2020). In addition, the homogeneity of the series was also assessed, using the RHtest package developed by Wang (2008a, 2008b), a program that contains statistical tests that check the significance of the points of change within the series, identify temporal noise, and harmonise the new data set.

\subsection{Climatological Water Balance}

The CWB estimate followed the model of Thornthwaite and Mather (1955) with the sequential approach, which considers all the months of the period under study. The other considerations were described by Souza and Nascimento (2020) and dealt with the calculation of 
potential evapotranspiration and soil water storage capacity for each municipality. According to Muniz Jr. et al. (2020), water entry is precipitation in this model, while evapotranspiration represents the exit. Thus, the amount of water that exceeds or remains to reach the soil's capacity becomes surplus or water deficit, respectively.

In a first scenario, the trend analysis (classical approach) was carried out on the annual and seasonal historical series of each municipality situated in the Paraguaçu for three different variables: rainfall, the input in the method of Thornthwaite and Mather (1955); water surplus; and water deficit. The latter represents two of the main interdependent variables generated in the CWB calculation. The average annual historical series of each division of the studied hydrographic region comprises the second scenario of the trend analysis, which compared the Mann-Kendall test with the ITA.

\subsection{Mann-Kendall Test}

The Mann-Kendall statistical model (MANN, 1945; KENDALL, 1975) is widely used in studies of trends in hydroclimatic data (CALOIERO; COSCARELLI; FERRARI, 2018; AZAM et $a l ., 2018)$. It applies appropriately because it is a sequential and non-parametric method, eliminating the assumption of normal data distribution (PHUONG et al., 2019). Each value in the series must be compared with the following values, defining the $S_{M K}$ statistic presented in Eq. 1 and Eq. 2, where $n$ is the length of the data set and $x_{i}$ and $x_{j}$ represent the values at times $i$ and $j$.

$$
\begin{gathered}
S_{M K}=\sum_{i=1}^{n-1} \sum_{j=i+1}^{n} \operatorname{sign}\left(x_{j}-x_{i}\right) \\
\operatorname{sign}\left(x_{j}-x_{i}\right)=\left\{\begin{array}{rr}
+1, & \text { if }\left(x_{j}-x_{i}\right)>0 \\
0, & \text { if }\left(x_{j}-x_{i}\right)=0 \\
-1, & \text { if }\left(x_{j}-x_{i}\right)<0
\end{array}\right.
\end{gathered}
$$

According to Phuong et al. (2019), when the series has a quantity of data greater than or equal to 10 , the $S_{M K}$ statistic approaches a normal distribution with null mean and variance defined by Eq. 3, where $m$ is the number of groups tied in the time series and $t$ is the number of ties in extension $k$.

$$
\operatorname{Var}\left(S_{M K}\right)=\frac{\left[n(n-1)(2 n+5)-\sum_{k=1}^{m} t_{k}\left(t_{k}-1\right)\left(2 t_{k}+5\right)\right]}{18}
$$


Finally, the $Z_{M K}$ statistic test can be calculated, following Eq. 4. This parameter indicates whether the trend is increasing (positive value) or decreasing (negative value) and if it is significant at a certain level of confidence.

$$
Z_{M K}= \begin{cases}\frac{S_{M K}-1}{\sqrt{\operatorname{Var}\left(S_{M K}\right)},} & \text { if } S_{M K}>0 \\ 0, & \text { if } S_{M K}=0 \\ \frac{S_{M K}+1}{\sqrt{\operatorname{Var}\left(S_{M K}\right)},} & \text { if } S_{M K}<0\end{cases}
$$

The present study adopted a significance level of $5 \%$, with a limit $Z$ value of 1.96 for significance, following the standard normal cumulative distribution table. For each municipality in the Paraguaçu, the results obtained for the MK test were presented through maps that depict the geographical positioning of trends in a visual way, as already recorded in similar studies (DENG et al., 2018; PHUONG et al., 2019; PRĂVĂLIE et al., 2019; WANG et al., 2020).

\subsection{Sen's Slope Estimator}

Sen's method (1968) has followed the application of the MK test, adding the idea of magnitude to trends by determining the slope between consecutive data points. As presented in Eq. 5 , Sen's slope factor $(\beta)$ is the median of all slopes over the entire period.

$$
\beta=\operatorname{med}\left(\frac{x_{j}-x_{i}}{j-i}\right)
$$

The answers obtained for the magnitude of the trends were obtained in the 50 municipalities (belonging to the limit and around the Paraguaçu hydrographic region), since they were presented through spatial distribution with the aid of interpolation, similar to that carried out in other studies (AYDOĞAN; AYAT, 2018; AZAM et al., 2018; DENG et al., 2018). Therefore, the deterministic IDW method was used in the spatialisation of different statistical trend results (PHUONG et al., 2019; SHARMA; SINGH, 2019; TEHRANI; SAHOUR; BOOIJ, 2019).

\subsection{Innovative Trend Analysis}

The concept introduced by Şen (2012) consists of dividing the time series into two equal parts. The two subseries are organised in ascending order and plotted on the Cartesian plane. The first half of the data is located on the $\mathrm{X}$-axis and the second half on the Y-axis. The dispersion of the data must be compared with the $1: 1$ line $\left(45^{\circ}\right)$, and the trend is increasing if the points are above 
the 1:1 line and decreasing when they are below. In this graph, two confidence bands were also presented, representing a difference of $\pm 10 \%$ from the general average of the data (TOSUNOGLU; KISI, 2016), in order to help the reader better capture the variation between the points of dispersion and the trendless line, with no statistical implications (ALIFUJIANG et al., 2020).

The significance of the trend verified by the ITA is assessed according to the methodology proposed by Şen (2017), which consists of comparing the slope of the line that represents the scattered points with confidence limits determined based on the standard deviation of the sampling slope and the correlation of the data. Following Eq. 6, the slope $s$ of the trend can be calculated, considering that $\bar{y}_{1}$ and $\bar{y}_{2}$ are the average values of the first and second half of the series, respectively. Positive $s$ values indicate a general growth trend, while negative values indicate a decrease (MALIK et al., 2019).

$$
s=\frac{2\left(\bar{y}_{2}-\bar{y}_{1}\right)}{n}
$$

The standard deviation of the sampling slope $\left(\sigma_{s}\right)$ is calculated based on Eq. 7, where: $\sigma$ is the standard deviation of the historical series and $\rho_{\bar{y}_{1} \bar{y}_{2}}$ is the correlation coefficient between the two subseries ordered in increasing order.

$$
\sigma_{s}=\frac{2 \sqrt{2}}{n \sqrt{n}} \sigma \sqrt{1-\rho_{\bar{y}_{1} \bar{y}_{2}}}
$$

According to Zhou et al. (2018), when applying the ITA, the Gaussian PDF of zero mean and standard deviation $\sigma_{s}$, is considered as the significance criterion, with the confidence limit $\left(s_{c r i}\right)$ continuing to follow the normal distribution table and depending on the level of significance. Thus, the upper and lower confidence limits of the ITA slope $(C L)$ are determined using Eq. 8.

$$
C L_{(1-\alpha)}=0 \pm s_{c r i} \sigma_{s}
$$

In this stage of the analysis, the significance level of $5 \%$ was also adopted, with a value for $s_{c r i}$ equal to 1.96. In this way, the slope of the trend of each series starts to have its confidence limit, which, when exceeded, indicates the acceptance of the alternative hypothesis of the statistical test, pointing out the significant trend.

The ITA method has some advantages over traditional methods, such as: allowing visual inspection of trends, generating new interpretations; admitting the possibility of sub-trends in the low, medium and high values of the series; being a straightforward calculation model; and not being 
influenced by the size of the time series (KISI, 2015; WU; QUIAN, 2017; ZHOU et al., 2018; ALI et al., 2019).

\section{RESULTS AND DISCUSSION}

Trends in rainfall, deficit and water surplus by the traditional MK method are summarised in Table 2. The results point to the dominance of negative values in precipitation, positive in deficit and negative/null in water surplus, most non-significant trends.

Some municipalities showed recurrence in the significance of the trend for the same variable in different scenarios. This is the rainfall and water deficit case in Canarana (3), which showed significant trends in four of the five periods analysed. The situation is repeated with the water deficit in Iramaia (9), which only shows significant trends in the autumn. Finally, Mucugê (18) stands out for presenting significant positive trends for the water deficit in all periods considered, except autumn. Such recurrences have been seen in previous trend studies, as in Zhou et al. (2018), who appreciate the importance of this aspect by the planning agencies.

Table 2: Values of $Z_{M K}$ for the MK test, considering the annual (An) and seasonal variables of summer (Su), autumn $(\mathrm{Au})$, winter $(\mathrm{Wi})$ and spring $(\mathrm{Sp})$. Note: ${ }^{*}$ Trend at the $5 \%$ significant level.

\begin{tabular}{|c|c|c|c|c|c|c|c|c|c|c|c|c|c|c|c|}
\hline \multirow{2}{*}{$\begin{array}{c}\text { Station } \\
\text { ID }\end{array}$} & \multicolumn{5}{|c|}{$Z_{M K}$ of rainfall } & \multicolumn{5}{|c|}{$Z_{M K}$ of Water Deficit } & \multicolumn{5}{|c|}{$Z_{M K}$ of Water Surplus } \\
\hline & An & Su & Au & Wi & Sp & An & Su & $\mathbf{A u}$ & Wi & Sp & An & Su & $\mathbf{A u}$ & Wi & Sp \\
\hline 1 & -0.25 & -0.14 & 1.07 & 0.37 & -0.50 & 0.21 & 0.66 & -0.82 & -0.18 & 0.96 & -0.78 & -0.27 & 0.38 & 0.00 & -1.24 \\
\hline 2 & -0.29 & 0.18 & 1.28 & $2.32 *$ & -1.03 & 0.29 & 0.14 & -0.89 & $-2.67 *$ & 0.41 & -0.86 & -0.56 & 0.26 & 0.77 & -1.77 \\
\hline 3 & $-2.03 *$ & $-2.89 *$ & $2.57^{*}$ & $3.31 *$ & -1.71 & $2.78 *$ & $3.25 *$ & 0.61 & $-2.46^{*}$ & $2.25 *$ & $-2.16^{*}$ & -1.25 & 0.00 & 0.00 & -1.58 \\
\hline 4 & -0.29 & 1.37 & 0.89 & 0.29 & $-2.46^{*}$ & -0.89 & $-2.07 *$ & -1.16 & 1.32 & 1.46 & -0.98 & -0.52 & 0.05 & -0.49 & -1.41 \\
\hline 5 & -0.04 & 1.53 & 1.39 & -0.96 & -1.36 & 0.64 & 0.79 & -1.89 & -0.07 & $2.18^{*}$ & 0.00 & 0.88 & 0.10 & 1.41 & -1.58 \\
\hline 6 & -1.11 & 0.04 & -1.36 & -0.46 & -1.36 & 1.82 & 0.00 & 1.18 & 1.03 & $2.00 *$ & -0.80 & -0.15 & -0.69 & 0.00 & -0.86 \\
\hline 7 & 0.68 & $-2.64 *$ & $2.03 *$ & $3.62 *$ & -1.16 & 0.32 & $3.36^{*}$ & -0.50 & $-3.21 *$ & 1.32 & $-2.79^{*}$ & -1.31 & $-2.31 *$ & 0.00 & -1.50 \\
\hline 8 & $-2.78 *$ & $-2.25 *$ & -1.84 & -1.28 & -0.79 & $2.39 *$ & $2.86^{*}$ & 1.68 & 1.64 & 1.53 & $-2.70^{*}$ & -0.52 & -1.95 & $-2.11^{*}$ & -1.62 \\
\hline 9 & -1.14 & -1.53 & 0.43 & $4.26^{*}$ & -1.57 & $2.89 *$ & $3.03 *$ & -0.57 & $-3.68^{*}$ & $3.25^{*}$ & -0.58 & 0.38 & 0.00 & 0.00 & -1.62 \\
\hline 10 & $\begin{array}{l}-1.68 \\
\end{array}$ & -0.32 & -0.82 & -1.37 & -1.50 & 1.82 & 0.54 & 0.68 & 1.78 & 1.86 & -0.26 & 0.82 & -0.69 & 0.00 & -1.49 \\
\hline 11 & -0.79 & -0.25 & 0.46 & -0.04 & -0.45 & 1.39 & 1.00 & -0.61 & -0.18 & 1.50 & -0.51 & 0.00 & 0.00 & 0.00 & -0.16 \\
\hline 12 & -1.82 & -1.39 & -0.68 & 0.39 & $-2.68^{*}$ & $2.25 *$ & 1.07 & 1.14 & 1.86 & $3.07 *$ & -1.33 & -0.12 & 0.00 & 0.00 & -1.62 \\
\hline 13 & -0.14 & 1.00 & 0.50 & -0.43 & -1.14 & 0.89 & 0.84 & -0.75 & 0.64 & 0.87 & -0.67 & -0.34 & -0.26 & 0.00 & $-2.25 *$ \\
\hline 14 & -1.62 & -0.50 & $\begin{array}{l}-0.82 \\
\end{array}$ & $-2.50 *$ & 0.43 & $2.25 *$ & 0.21 & 1.21 & $2.28^{*}$ & 1.53 & 0.52 & $\begin{array}{l}-0.08 \\
\end{array}$ & 0.23 & 0.00 & -0.17 \\
\hline 15 & -0.82 & -0.54 & 0.27 & 1.91 & -0.73 & 0.68 & 0.98 & 0.86 & -0.54 & 0.64 & -0.99 & 0.00 & -0.08 & 0.00 & -1.31 \\
\hline 16 & 0.79 & 0.07 & 0.29 & $3.05 *$ & -1.32 & 0.00 & 0.79 & 0.29 & $-2.36^{*}$ & 1.57 & -1.35 & -0.33 & 0.00 & 0.00 & -1.62 \\
\hline 17 & -1.36 & -0.36 & -1.07 & -0.11 & -1.93 & $2.21^{*}$ & 1.00 & 0.82 & 1.64 & 1.39 & -1.13 & -0.17 & -0.77 & 0.00 & -1.94 \\
\hline 18 & $-2.36^{*}$ & -1.14 & -1.00 & -1.64 & $-2.32 *$ & $3.39 *$ & $2.59 *$ & 1.75 & $2.18^{*}$ & $2.59 *$ & $-2.57^{*}$ & -1.79 & -0.07 & 0.00 & $-2.49 *$ \\
\hline 19 & -1.36 & -0.61 & 0.18 & -0.04 & -0.25 & 1.61 & 1.03 & 0.52 & 0.93 & 0.89 & -0.82 & -1.04 & -1.28 & -0.70 & -0.10 \\
\hline 20 & -0.79 & -0.86 & -0.41 & -1.82 & -0.43 & 1.64 & 1.32 & 1.21 & 1.82 & -0.11 & -0.10 & 0.00 & 0.23 & 0.00 & -0.28 \\
\hline 21 & -1.61 & -0.75 & 0.07 & -0.11 & -1.75 & 1.03 & 0.50 & -0.21 & -0.18 & 1.89 & $-2.10^{*}$ & -1.12 & -0.33 & 1.04 & $-2.45 *$ \\
\hline 22 & -1.21 & 0.11 & -0.14 & 1.21 & -1.07 & 1.28 & 0.32 & 0.00 & 0.32 & 1.11 & -1.38 & -0.06 & -0.69 & 0.00 & -1.91 \\
\hline 23 & $-2.96 *$ & -0.89 & -1.16 & -1.71 & $-2.39 *$ & $3.25 *$ & 1.43 & 1.36 & $2.46^{*}$ & $1.96^{*}$ & -1.16 & 0.00 & 0.00 & 0.00 & -1.62 \\
\hline 24 & $-2.39^{*}$ & -1.14 & 0.48 & $2.07^{*}$ & $-2.60^{*}$ & $3.25 *$ & $2.82 *$ & 0.54 & -1.28 & $2.96^{*}$ & -1.77 & -0.52 & 0.00 & 0.00 & -1.61 \\
\hline 25 & -1.03 & -0.46 & 0.04 & -0.61 & -0.23 & 0.54 & 0.57 & -0.25 & 0.25 & -0.36 & 0.15 & 0.15 & 0.00 & 0.00 & 0.00 \\
\hline 26 & 0.29 & -0.07 & 1.86 & 1.34 & -1.11 & -0.54 & 0.50 & -1.21 & $-2.82 *$ & -0.07 & -0.26 & 0.39 & 0.00 & 0.00 & -0.75 \\
\hline 27 & -1.32 & -0.32 & -0.32 & -0.93 & -1.46 & $2.07 *$ & $2.14 *$ & 0.64 & 1.07 & $2.11 *$ & -0.89 & -0.15 & 0.52 & 0.00 & -1.37 \\
\hline
\end{tabular}

Source: Prepared by the authors, 2020.

The results obtained by the MK test and Sen's slope estimator were represented geographically in Figures 2-5. Figure 2 presents the trends for the three annual variables in the period between 1989 and 2018. For rainfall (Figure 2a), it is noted that the trend of decline in the precipitated volume was predominant across the hydrographic region, with magnitudes of reduction of up to $20 \mathrm{~mm}$ per year and with three points of a significant trend in the extreme west of the upper 
Paraguaçu. This location exhibits high rainfall levels during this period, according to Souza and Nascimento (2021). This general trend of decreasing rainfall can influence the occurrence of eventual droughts, as indicated by Wu and Quian (2017).

Figure $2 \mathrm{~b}$ presents the results for the water deficit, and the scenario is reversed, observing the predominance of largely significant growth trends. Water deficiency is significant, in general, in the entire hydrographic region (SOUZA; NASCIMENTO, 2020), and the increase in this indicator reaches $12 \mathrm{~mm}$ per year. Water surplus (Figure 2c) almost always showed decreasing trends, with a maximum rate of $10 \mathrm{~mm}$ per year in the municipality of Mucugê. The recurrence of values equal to zero in the time series of surpluses sometimes resulted in the absence of a trend by the MK test and other times in the annulment of the magnitude. The latter is represented by the hegemony of the intermediate chromatic scale in the water surplus maps.

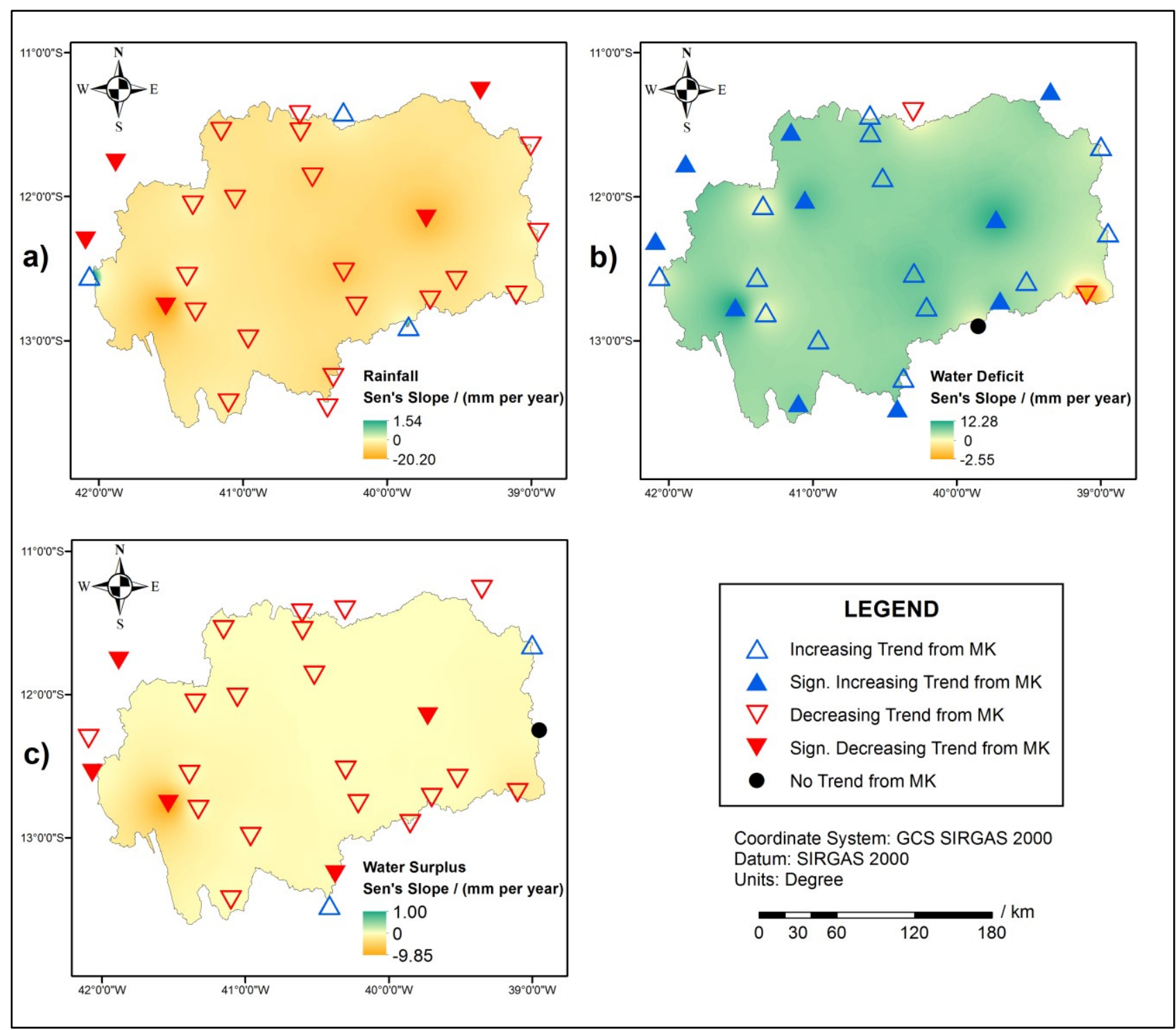

Figure 2 - Results of trend detection in the annual data of rainfall (a), water deficit (b) and water surplus (c), using the Mann-Kendall test and Sen's slope estimator in the hydrographic region of Paraguaçu.

Source: Prepared by the authors, 2020. 
Prior to the analysis of seasonal trends, it is necessary to emphasise that the rainy season in the upper and middle Paraguaçu occurs in the summer and spring seasons (between November and April), while in the lower Paraguaçu, it occurs in the autumn and early winter (between April and July). Deficits grow in a west-east direction in summer and spring. In other seasons, they are quite small, except the south-central and southwest portions of the hydrographic region. Surpluses are practically nil throughout the year, except in summer and spring in the far west and autumn and winter in the far east (SOUZA; NASCIMENTO, 2020, 2021).

On the seasonal scale, the trends in rainfall are essentially decreasing in the summer (Figure 3a) and the spring (Figure 3d), rainy seasons in the largest portion of the Paraguaçu. On the contrary, autumn (Figure 3b) and winter (Figure 3c) have more points with an increasing tendency concerning other seasons, with annual increments that reach almost $6 \mathrm{~mm}$. This behaviour of negative trends in precipitation during the wet period and positive during the dry period is quite common, having already been registered in the studies by Paul et al. (2017), Phuong et al. (2019) and Bezerra et al. (2021).

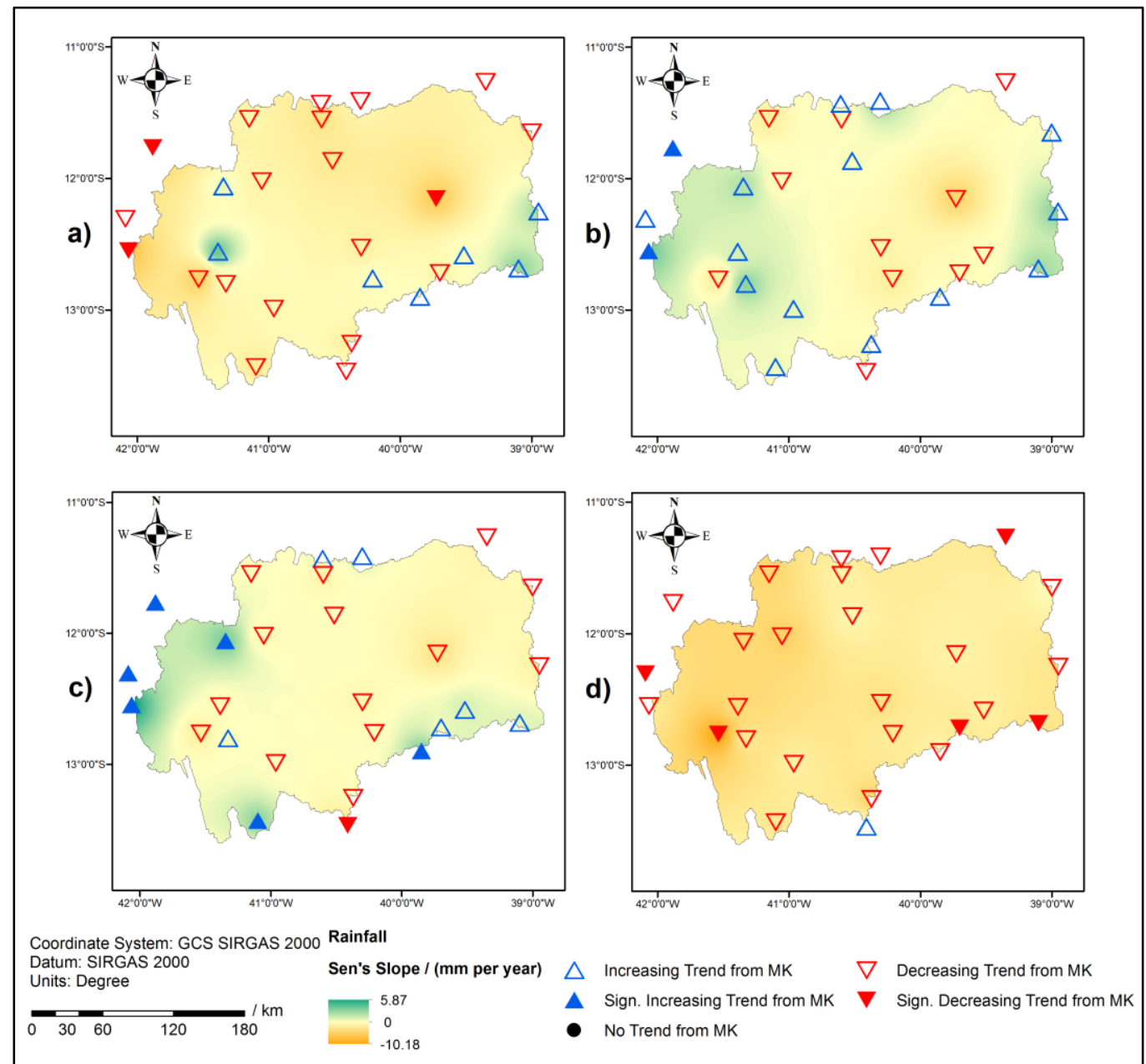

Figure 3 - Results of trend detection in the seasonal data of rainfall, using the Mann-Kendall test and Sen's slope estimator, considering the seasons: summer (a); autumn (b); winter (c); and spring (d).

Source: Prepared by the authors, 2020 . 
The positive trend points were concentrated in parts of the upper and lower Paraguaçu, and the first is at high altitudes. The second is closer to the ocean. These are exactly the geographical specificities pointed out by Mrad et al. (2018) to manifest positive trends in precipitation. However, it should also be noted that rainfall reductions of up to $10 \mathrm{~mm}$ per year are forecast in the spring in practically the entire region of Paraguaçu.

Conversely, water deficit trends are essentially increasing in the summer (Figure 4a) and the spring (Figure 4d), although this variable is less expressive in the upper Paraguaçu in these seasons. The autumn (Figure 4b) and winter (Figure 4c) seasons, characterised by reduced deficits throughout the entire hydrographic region, are those that have more points with a tendency to decrease water deficiency, especially in the upper and lower Paraguaçu, with annual decreases up to $5 \mathrm{~mm}$.
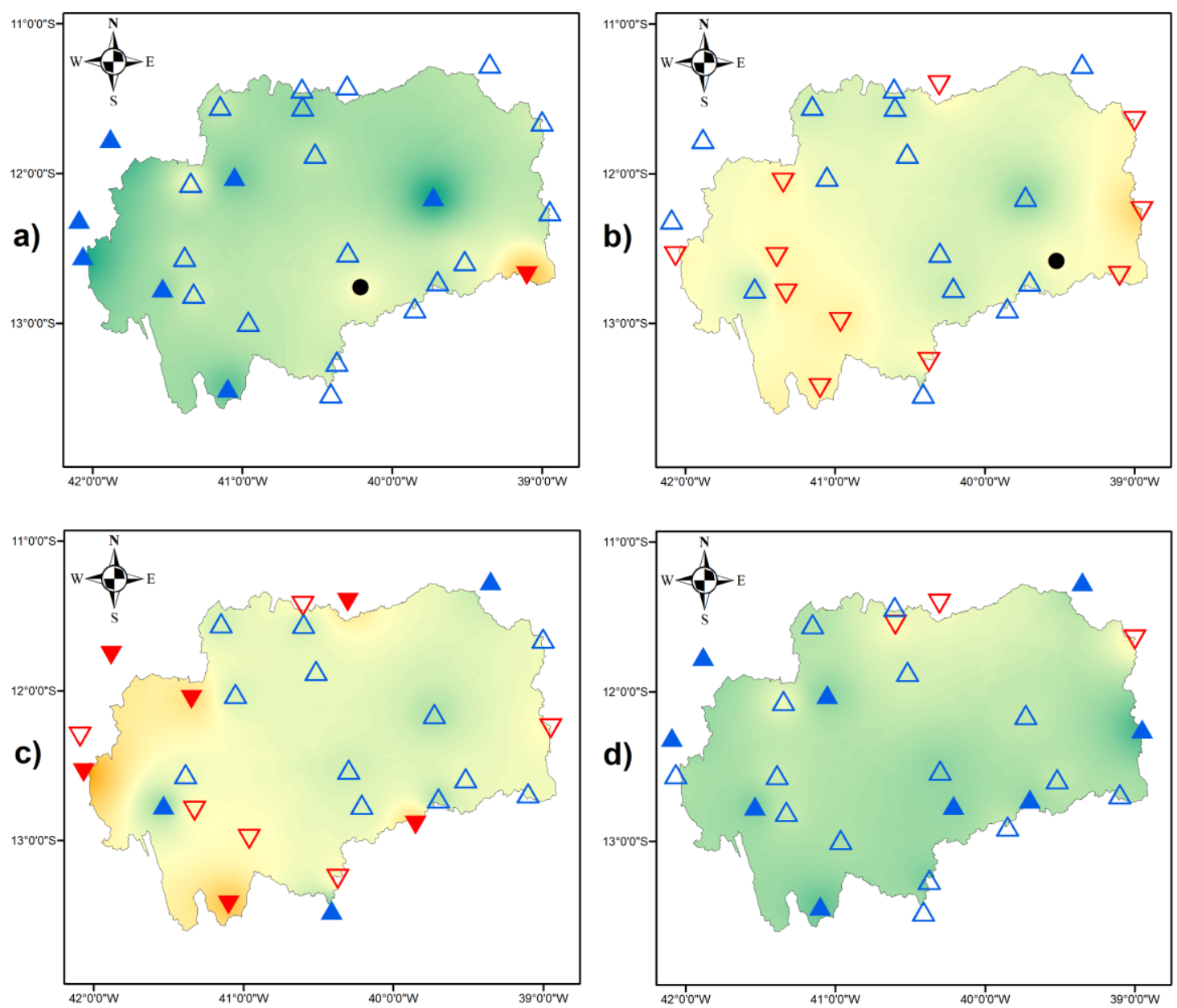

Coordinate System: GCS SIRGAS 2000 Water Deficit Datum: SIRGAS 2000 Units: Degree


Figure 4 - Results of trend detection in the seasonal data of water deficit, using the Mann-Kendall test and Sen's slope estimator, considering the seasons: summer (a); autumn (b); winter (c); and spring (d).

Source: Prepared by the authors, 2020. 
It is also worth noting that significant reductions in deficits are only foreseen in the winter and the far east during the summer period, with many significant positive trends being observed in the summer and spring. The limited amount of statistically significant reductions in deficits indicates that these locations in the hydrographic region have already experienced severe drought conditions over that time scale, according to Prăvălie et al., (2019).

The main reservoir in the hydrographic region is Pedra do Cavalo, located in the lower Paraguaçu, an area affected by negative rainfall trends and positive water deficiency trends only in the spring. This is interesting for maintaining the activities that depend on this reservoir, such as supplying the metropolitan areas of Feira de Santana and Salvador, generating electricity, and controlling floods (SANTO; CARELLI, 2016).

Other reservoirs in the middle Paraguaçu are likely to be affected by negative trends in rainfall and positive water deficits throughout the year, compromising the viability of the multiple uses developed in the region, consisting mainly of agriculture, pastures and flow regularisation (SANTO; CARELLI, 2016). Furthermore, the trends in reducing rainfall and increasing deficiency in the rainy season in the upper Paraguaçu (summer and spring) are of concern, especially due to the recurrent restrictions on access to water due to pollution and silting of rivers (MIRANDA et al., 2016).

The surplus behaves peculiarly concerning trends. Summer (Figure 5a) and spring (Figure 5d), seasons of a high water surplus in the upper Paraguaçu, show slightly more tendencies to decrease this variable, especially in this sub-region. On the other hand, in autumn (Figure 5b), the forecast for an increase in surpluses is indicated in some points, including the extreme east, while in winter (Figure 5c), the highest number of points with no trends was registered, due to the absence of expression of this CWB phenomenon in that period.

It is also worth mentioning that the trend magnitudes are less than $1 \mathrm{~mm}$ per year, not being so relevant, which is even derived from the intermediate chromatic scale of the maps, due to the zero value of most of the Sen's slope estimators. In the Paraguaçu region, the season that contributes the most, with almost $50 \%$ of the annual water surplus, is the summer, indicating that the trends of this season are similar and have a direct impact on the annual trends of the surpluses (Figure 2c), as highlighted by Azam et al., (2018). 


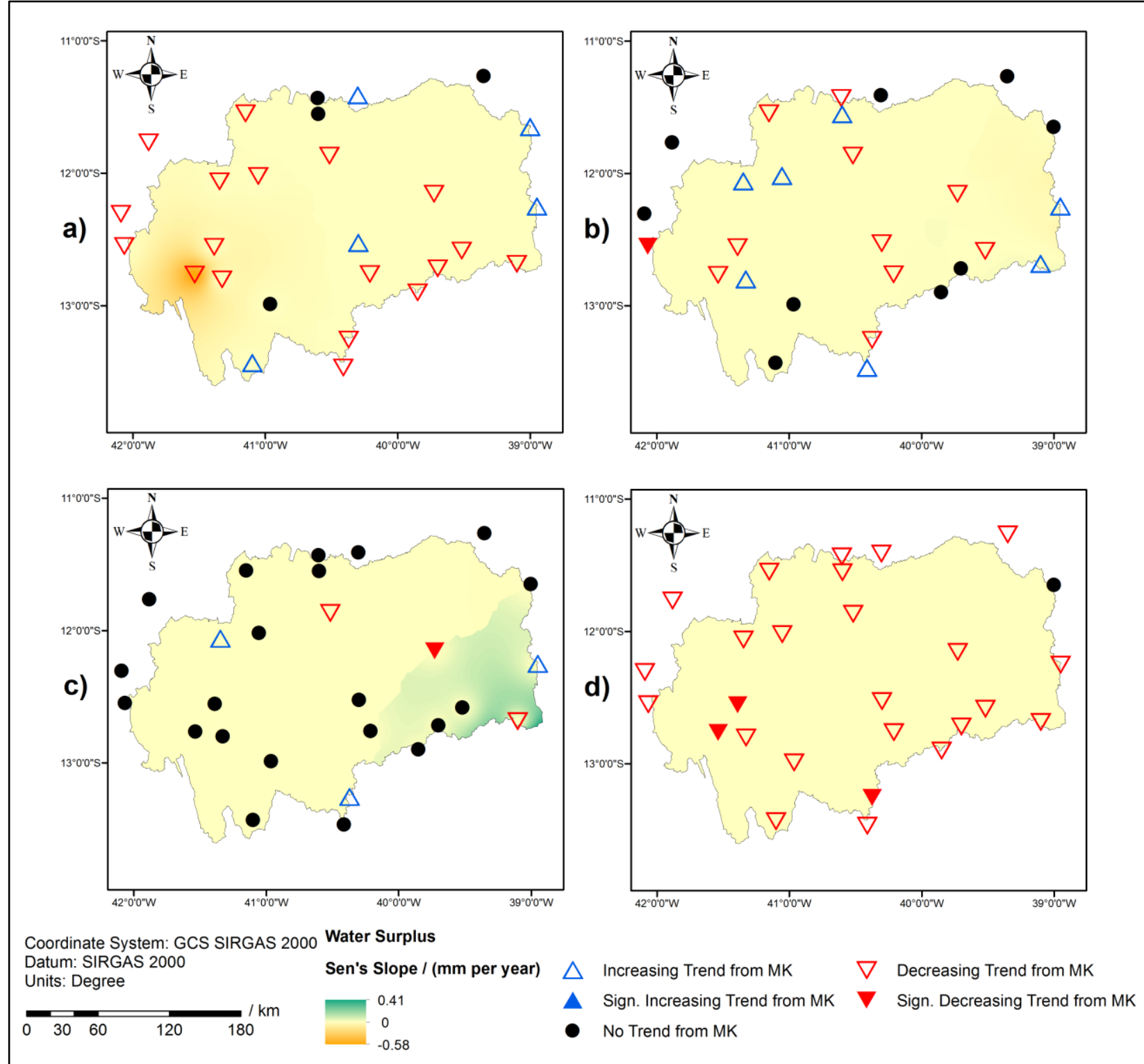

Figure 5 - Results of trend detection in the seasonal data of water surplus, using the Mann-Kendall test and Sen's slope estimator, considering the seasons: summer (a); autumn (b); winter (c); and spring (d).

Source: Prepared by the authors, 2020.

The percentage of stations with positive, negative or null trends, significant or not, and in each time scale analysed, is summarised in Figure 6. Annually, the water availability scenario in the Paraguaçu is critical, with the same rate of $88.9 \%$ for rainfall and water surplus decreasing and deficit-increasing, regardless of significance. This high percentage in the scenarios of reduced rainfall and surpluses and increased water deficit implies a reduction in water availability that affects human supply, irrigation, and soil moisture (HUI-MEAN; YUSOP; YUSOF, 2018).

Seasonally, a trend variability can be verified according to the season. For example, precipitation (Figure 6a) exceeds $44 \%$ of positive trends in autumn and winter, seasons in which the deficit (Figure $6 \mathrm{~b}$ ) showed a downward trend in more than $40 \%$ of stations, indicating that this period may be the most promising in terms of supply of water resources. As for the surplus (Figure 
6c), there are more points without trends in the historical series. Additionally, the trends relative to the increase in the values of this variable do not exceed $26 \%$ in any period.



Figure 6 - Relative frequency trends (1989-2018 period) of rainfall (a), water deficit (b) and water surplus (c) on the different temporal scales, according to the direction (positive/ negative/ stationary) and statistical significance (significant/ insignificant). Source: Prepared by the authors, 2020.

The trends detected for rainfall and CWB indices for each sub-region of the Paraguaçu, by two different methods (MK and ITA), are summarised in Table 3. The MK results show that the statistics are negative for precipitation and water surplus and positive for the deficit, with significant values observed on only three occasions, already glimpsed in the regionalisation of specific trends (Figure 2): in the increase of deficits in the upper and middle Paraguaçu and the reduction of the surpluses in the lower Paraguaçu.

The results of the ITA show that the trends are the same as those found by MK, with the slopes being negative for precipitation and water surplus and positive for the water deficit. This similarity between the methods was also verified in other studies (CUI et al., 2017; CALOIERO; COSCARELLI; FERRARI, 2018). The big difference between them lies in the fact that the ITA is significant in $100 \%$ of the trends. As noted by Zhou et al. (2018), this situation reveals that many significant trends, which are not identified by the Mann-Kendall test, end up being detected through the ITA, benefiting the trend analysis. 
Table 3: The Mann-Kendall and the innovative trend test results, considering the annual variables average in each subregion of Paraguaçu. Note: *Trend at the $5 \%$ significant level.

\begin{tabular}{|c|c|c|c|c|c|c|c|}
\hline $\begin{array}{l}\text { Sub-region of } \\
\text { Paraguaçu }\end{array}$ & $Z_{M K}$ & $\begin{array}{c}\text { Standard } \\
\text { deviation } \sigma\end{array}$ & $\begin{array}{c}\text { Correlation } \\
\rho_{\bar{y}_{1} \bar{y}_{2}}\end{array}$ & $\begin{array}{l}\text { Slope Standard } \\
\text { Deviation } \sigma_{s}\end{array}$ & $\begin{array}{l}\text { Lower } \\
\quad C L\end{array}$ & $\begin{array}{l}\text { Upper } \\
\quad C L\end{array}$ & $\begin{array}{c}\text { Slope } \\
\quad S\end{array}$ \\
\hline \multicolumn{8}{|c|}{ Rainfall } \\
\hline Upper & -1.28 & 202.7 & 0.94 & 0.85 & -1.68 & 1.68 & $-3.27 *$ \\
\hline Middle & -1.78 & 149.1 & 0.85 & 0.99 & -1.94 & 1.94 & $-4.88^{*}$ \\
\hline Lower & -0.86 & 138.4 & 0.99 & 0.19 & -0.37 & 0.37 & $-2.07 *$ \\
\hline \multicolumn{8}{|c|}{ Water Deficit } \\
\hline Upper & $2.25^{*}$ & 144.8 & 0.97 & 0.41 & -0.80 & 0.80 & $4.07^{*}$ \\
\hline Middle & $2.50 *$ & 116.0 & 0.92 & 0.56 & -1.09 & 1.09 & $4.39 *$ \\
\hline Lower & 0.68 & 118.0 & 0.96 & 0.41 & -0.81 & 0.81 & $2.28 *$ \\
\hline \multicolumn{8}{|c|}{ Water Surplus } \\
\hline Upper & -1.95 & 106.9 & 0.96 & 0.35 & -0.69 & 0.69 & $-3.12 *$ \\
\hline Middle & -1.24 & 67.6 & 0.98 & 0.14 & -0.28 & 0.28 & $-2.12 *$ \\
\hline Lower & $-2.36 *$ & 42.6 & 0.94 & 0.17 & -0.34 & 0.34 & $-2.12 *$ \\
\hline
\end{tabular}

Source: Prepared by the authors, 2020.

The results obtained through the ITA method are shown in Figures 7-9. For the pluviometric precipitation (Figure 7), the variation of the position of the points concerning the 1:1 line is notable, which influences the divergence between the trends in low, moderate, and high rainfall. In each group of values, different annual rainfall trends in the same location were also noted by Wang et al. (2020). For example, in the upper Paraguaçu (Figure 7a), rainfall around $400 \mathrm{~mm}$ and above $800 \mathrm{~mm}$ per year tends to decrease, the latter being significant in terms of the $10 \%$ band. In contrast, moderate rainfall has an increasing tendency.

Precipitation in the middle Paraguaçu (Figure 7b) has a similar dispersion, with a downward trend of up to $400 \mathrm{~mm}$ and above $600 \mathrm{~mm}$ annually, indicating that the range of precipitation with a growing trend is smaller in this region affected by the semi-arid region. However, in the lower Paraguaçu (Figure 7c), the behaviour is slightly different since the trend increases for up to $600 \mathrm{~mm}$ per year for precipitations. It starts to decrease when this value is exceeded, without any significance concerning the $10 \%$ band.

The results of the ITA for trends in water deficit in the Paraguaçu are more monotonic since few points differ from most of the positions about the 1:1 line. Therefore, the trends presented in the three sub-regions generally represent an increase in deficits, up to nearly $400 \mathrm{~mm}$ per year, at the top (Figure 8a) and the lower Paraguaçu (Figure 8c). The upward trend is significant concerning the $10 \%$ band. In the middle Paraguaçu (Figure $8 \mathrm{~b}$ ), this most expressive growth trend extends to close to $600 \mathrm{~mm}$, aggravating the water deficiency scenario in a sub-region already affected by high temperatures and low rainfall. 

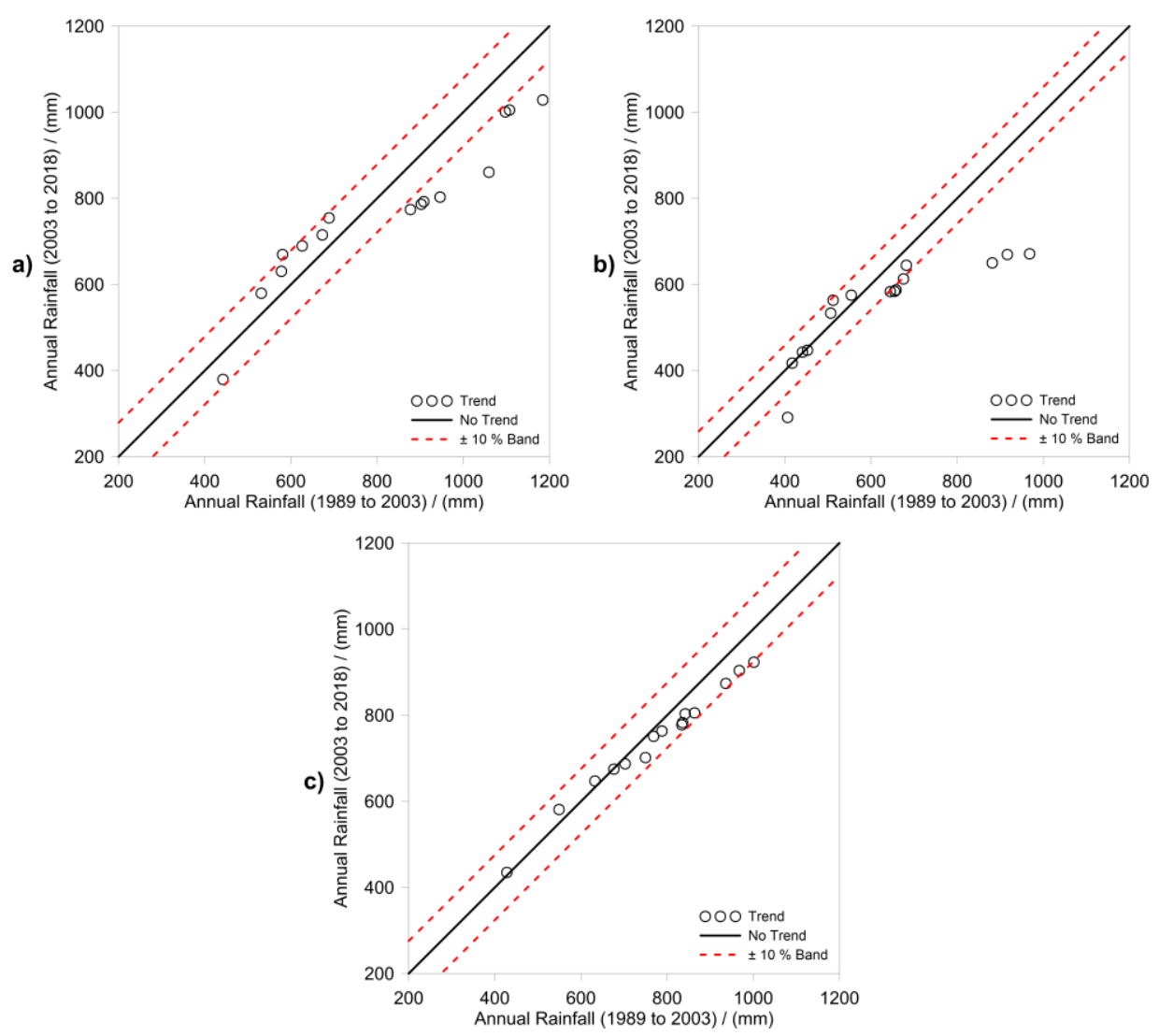

Figure 7 - Results of the ITA method at annual scale for the rainfall in the sub-regions of Paraguaçu: upper (a), middle (b), and lower (c). Source: Prepared by the authors, 2020.


Figure 8 - Results of the ITA method at annual scale for the water deficit in the sub-regions of Paraguaçu: upper (a), middle (b), and lower (c). Source: Prepared by the authors, 2020. 
The most accentuated trends found using the ITA method occurred for the water surplus variable (Figure 9). In general, there are monotonic tendencies to reduce surpluses, with the largest one being significant to the $10 \%$ band in all sub-regions. The upper Paraguaçu (Figure 9a) shows the highest average water surplus accumulated in one year. The reduction trends become relevant after $100 \mathrm{~mm}$. In the middle Paraguaçu (Figure 9b), the low average volume of surpluses results in points of dispersion accumulated at the beginning of the 1:1 line, indicating little or no trend up to $50 \mathrm{~mm}$ annually.

Finally, the lower Paraguaçu (Figure 9c) exhibited a more regular decreasing trend of approximately $120 \mathrm{~mm}$, with less relevance regarding the $10 \%$ band. Significance by the MK method occurred only in this last sub-region, with the most accentuated trends occurring in the graphs of the previous sub-regions. The ITA method foreshadowed significant trends in the three divisions, resuming the advantage of this model in terms of the perception of hidden variation of trends through graphic illustration, as pointed out by Malik et al. (2019).


Figure 9 - Results of the ITA method at annual scale for the water surplus in the sub-regions of Paraguaçu: upper (a), middle (b), and lower (c). Source: Prepared by the authors, 2020 
The results of the ITA are satisfactory to the point that they serve well the purpose of detecting trends in different data ranges, providing greater power of visual inspection and later interpretations, as already noted by Caloiero, Coscarelli and Ferrari (2018). However, what still needs improvement, in the graphical method of Şen (2012), is the direct detection of significance from the distance of the points to the neutral line $(1: 1)$, since the $10 \%$ band has no statistical value and the assessment of significance in the ITA (SSEN, 2017) is limited to comparing the slope of the trend with the confidence limits.

Another important aspect of the proportion of significant trends detected by ITA concerning MK, since other studies (ZHOU et al., 2018; MALIK et al., 2019; WANG et al., 2020) also attested that many ITA trends are significant. Therefore, most of these authors positively see this issue as gaps in MK that do not allow the verification of significance, without considering that this may demand an excessive concern about the local hydroclimatic scenario, without so much need in the short term.

\section{CONCLUSIONS}

Annually, traditional methods indicate negative trends in rainfall, positive in deficit and negative/null in water surplus, the vast majority of which are not significant.

Seasonally, the seasons considered dry (autumn and winter) were the ones that presented the greatest amount of trends in the increase of rainfall and decrease of water deficit, indicating that these seasons can be determinants for possible changes in water availability in the region.

The seasonal trends of water surpluses are peculiar. Most of the decrease in seasons, except in winter, presents most points with no trend in the historical series.

Annually, through innovative trend analysis, negative trends in rainfall, positive trends in water deficiency and negative trends in surpluses were reaffirmed in all the geographical divisions of the Paraguaçu.

In general, the MK and ITA methods showed similar results for indicating trends in the sub-regions of the Paraguaçu. However, ITA has shown a higher number of significant trends.

The visual and graphic aspects of the ITA method contributed to non-monotonic interpretations since it allows the detection of trends in low, medium, and high values within historical series.

\section{ACKNOWLEDGEMENTS}

This study was financed in part by the Coordenação de Aperfeiçoamento de Pessoal de Nível Superior - Brasil (CAPES) - Finance Code 001. The authors also thank the Programa de Pós- 
Graduação em Engenharia Civil e Ambiental (PPGECEA) and the Universidade Estadual de Feira de Santana (UEFS).

\section{REFERENCES}

ALI, R.; KURIQI, A.; ABUBAKER, S.; KISI, O. Long-term trends and seasonality detection of the observed flow in Yangtze River using Mann-Kendall and Sen's innovative trend method. Water, v. 11, n. 9, p. 1855, 2019.

ALIFUJIANG, Y.; ABUDUWAILI, J.; MAIHEMUTI, B.; EMIN, B.; GROLL, M. Innovative Trend Analysis of Precipitation in the Lake Issyk-Kul Basin, Kyrgyzstan. Atmosphere, v. 11, n. 4, p. 332, 2020.

ANAND, J.; GOSAIN, A. K.; KHOSA, R.; SRINIVASAN, R. Regional scale hydrologic modeling for prediction of water balance. analysis of trends in streamflow and variations in streamflow: The case study of the Ganga River basin. Journal of Hydrology: Regional Studies, v. 16, p. 32-53, 2018.

ASFAW, A.; SIMANE, B.; HASSEN, A.; BANTIDER, A. Variability and time series trend analysis of rainfall and temperature in northcentral Ethiopia: A case study in Woleka sub-basin. Weather and Climate Extremes, v. 19, p. 29-41, 2018.

AYDOĞAN, B.; AYAT, B. Spatial variability of long-term trends of significant wave heights in the Black Sea. Applied Ocean Research, v. 79, p. 20-35, 2018.

AZAM, M.; MAENG, S. J.; KIM, H. S.; LEE, S. W.; LEE, J. E. Spatial and temporal trend analysis of precipitation and drought in South Korea. Water, v. 10, n. 6, p. 765, 2018.

Bezerra, A. C.; COSTA, S. A. T.; SIlva, J. L. B.; ARAÚJO, A. M. Q.; MOURA, G. B. A.; LOPES, P. M. O.; NASCIMENTO, C. R. Annual Rainfall in Pernambuco, Brazil: Regionalities, Regimes, and Time Trends. Revista Brasileira de Meteorologia, v. 36, n. 3, p. 403-414, 2021.

BRUBACHER, J. P.; OLIVEIRA, G. G.; GUASSELLI, L. A. Preenchimento de Falhas e Espacialização de Dados Pluviométricos: Desafios e Perspectivas. Revista Brasileira de Meteorologia, v. 35, n. 4, p. 615-629, 2020.

CALOIERO, T.; COSCARELLI, R.; FERRARI, E. Application of the innovative trend analysis method for the trend analysis of rainfall anomalies in southern Italy. Water Resources Management, v. 32, n. 15, p. 4971-4983, 2018.

CHANDNIHA, S. K.; MESHRAM, S. G.; ADAMOWSKI, J. F.; MESHRAM, C. Trend analysis of precipitation in Jharkhand State, India. Theoretical and Applied Climatology, v. 130, n. 1-2, p. 261-274, 2017.

CUI, L.; WANG, L.; LAI, Z.; TIAN, Q.; LIU, W.; LI, J. Innovative trend analysis of annual and seasonal air temperature and rainfall in the Yangtze River Basin, China during 1960-2015. Journal of Atmospheric and Solar-Terrestrial Physics, v. 164, p. 48-59, 2017. 
DENG, S.; CHEN, T.; YANG, N.; QU, L.; LI, M.; CHEN, D. Spatial and temporal distribution of rainfall and drought characteristics across the Pearl River basin. Science of the Total Environment, v. 619, p. 28-41, 2018.

GIORGI, F.; RAFFAELE, F.; COPPOLA, E. The response of precipitation characteristics to global warming from climate projections. Earth System Dynamics, v. 10, n. 1, p. 73-89, 2019.

HADI, S. J.; TOMBUL, M. Comparison of spatial interpolation methods of precipitation and temperature using multiple integration periods. Journal of the Indian Society of Remote Sensing, v. 46, n. 7, p. 1187-1199, 2018.

HUI-MEAN, F.; YUSOP, Z.; YUSOF, F. Drought analysis and water resource availability using standardised precipitation evapotranspiration index. Atmospheric Research, v. 201, p. 102-115, 2018.

INTERGOVERNMENTAL PANEL ON CLIMATE CHANGE - IPCC. Climate Change 2021: The Physical Science Basis. Contribution of Working Group I to the Sixth Assessment Report of the Intergovernmental Panel on Climate Change. In: MASSON-DELMOTTE, V.; ZHAI, P.; PIRANI, A.; CONNORS, S. L.; PÉAN, C.; BERGER, S.; CAUD, N.; CHEN, Y.; GOLDFARB, L.; GOMIS, M. I.; HUANG, M.; LEITZELL, K.; LONNOY, E.; MATTHEWS, J. B. R.; MAYCOCK, T. K.; WATERFIELD, T.; YELEKÇI, O.; YU, R.; ZHOU, B. (Eds.). Cambridge: Cambridge University Press, 2021. 3949p.

KENDALL, M. G. Rank Correlation Methods. Charles Griffin, London, 1975.

KHAN, N.; POUR, S. H.; SHAHID, S.; ISMAIL, T.; AHMED, K.; CHUNG, E.; NAWAZ, N.; WANG, X. Spatial distribution of secular trends in rainfall indices of Peninsular Malaysia in the presence of long-term persistence. Meteorological Applications, v. 26, n. 4, p. 655-670, 2019.

KISI, O. An innovative method for trend analysis of monthly pan evaporations. Journal of Hydrology, v. 527, p. 1123-1129, 2015.

MACEDO, M. J. H. Aplicações de redes neurais artificiais e satélite TRMM na modelagem chuva-vazão da bacia hidrográfica do rio Paraguaçu/BA. Campina Grande, 2013. $109 \mathrm{f}$. Tese (Doutorado em Meteorologia) - Universidade Federal de Campina Grande, Campina Grande, 2013.

MALIK, A.; KUMAR, A.; GUHATHAKURTA, P.; KISI, O. Spatial-temporal trend analysis of seasonal and annual rainfall (1966-2015) using innovative trend analysis method with significance test. Arabian Journal of Geosciences, v. 12, n. 10, p. 328, 2019.

MANN, H. B. Nonparametric tests against trend. Econometrica, v. 13, p. 245-259, 1945.

MEDEIROS, E. S.; LIMA, R. R.; OLINDA, R. A.; DANTAS, L. G.; SANTOS, C. A. C. SpaceTime Kriging of Precipitation: Modeling the Large-Scale Variation with Model GAMLSS. Water, v. 11, n. 11, p. 2368, 2019.

MIRANDA, R. M.; RITA, L. S.; GOLÇALVES, M. A. S.; MESQUITA, C. A. B.; RIGUEIRA, D. M. G.; ALMEIRA, E.; COUTINHO, B. H.; LAMAS, I. R. Conciliando políticas, governança e ciência para a revitalização. In: LAMAS, I. R.; RITA, L. S.; MIRANDA, R. M. (Orgs.). Semeando Águas no Paraguaçu. Rio de Janeiro: Conservação Internacional, 2016. p. 146-175. 
MOHAMMADI, M.; ABDOLLAHI, Z.; FOROZANFARD, M.; JAMALI, S. E.; SANG, Y. Trend variations of water balance components affected by climate changes (case study: Atrak river basin, Iran). Azarian Journal of Agriculture, v. 4, n. 3, p. 59-68, 2017.

MRAD, D.; DJEBBAR, Y.; HAMMAR, Y. Analysis of trend rainfall: Case of North-Eastern Algeria. Journal of Water and Land Development, v. 36, n. 01, p. 105-115, 2018.

MUNIZ JR., J. G. R.; OLIVEIRA JR., J. F.; GOIS, G.; SERAFINI, B.; SOBRAL, P. E. T.; SILVA JR., C. A.; CORREIA FILHO, W. L. F.; SANTIAGO, D. B. Climatological Water Balance In The Municipality of Rio de Janeiro. Revista Brasileira de Geografia Física, v. 13, n. 5, p. 2388-2401, 2020.

PAUL, A.; BHOWMIK, R; CHOWDARY, V. M.; DUTTA, D.; SREEDHAR, U.; SANKAR, H. R. Trend analysis of time series rainfall data using robust statistics. Journal of Water and Climate Change, v. 8, n. 4, p. 691-700, 2017.

PHUONG, D. N. D.; LINH, V. T.; NHAT, T. T.; DUNG, H. M.; LOI, N. K. Spatiotemporal variability of annual and seasonal rainfall time series in Ho Chi Minh city, Vietnam. Journal of Water and Climate Change, v. 10, n. 3, p. 658-670, 2019.

PRĂVĂLIE, R.; PITICAR, A.; ROȘCA, B.; SFÎCĂ, L.; BANDOC, G.; TISCOVSCHI, A.; PATRICHE, C. Spatio-temporal changes of the climatic water balance in Romania as a response to precipitation and reference evapotranspiration trends during 1961-2013. Catena, v. 172, p. 295312, 2019.

SANTO, S. M.; CARELLI, L. Bacia Hidrográfica do Paraguaçu: da Chapada Diamantina à Baía de Todos os Santos. In: LAMAS, I. R.; RITA, L. S.; MIRANDA, R. M. (Orgs.). Semeando Águas no Paraguaçu. Rio de Janeiro: Conservação Internacional, 2016. p. 12-33.

SEN, P. K. Estimates of the regression coefficient based on Kendall's tau. Journal of the American Statistical Association, v. 63, n. 324, p. 1379-1389, 1968.

ŞEN, Z. Innovative trend analysis methodology. Journal of Hydrologic Engineering, v. 17, n. 9, p. 1042-1046, 2012.

ŞEN, Z. Innovative trend significance test and applications. Theoretical and Applied Climatology, v. 127, n. 3-4, p. 939-947, 2017.

SHARMA, S.; SINGH, P. K. Spatial trends in rainfall seasonality: a case study in Jharkhand. India. Weather, v. 74, n. 1, p. 31-39, 2019.

Silva, G. O. M.; MEDEIROS, Y. D. P.; FONTES, A. S.; MONTENEGRO, S. M. G. L. Water permit integration in the Paraguaçu River Watershed (Bahia). Revista Brasileira de Recursos Hídricos, v. 22, p. 1-15, 2017.

SOUZA, T. S.; NASCIMENTO, P. S. Spatial and temporal variability of pluviometric precipitation in the hydrographic region of Paraguaçu - BA. Revista Cerrados, v. 19, n. 1, p. 203-229, 2021.

SOUZA, T. S.; NASCIMENTO, P. S. Sequential Climatic Water Balance applied in the hydrographic region of Paraguaçu, in Brazil. 2020. (Artigo científico submetido para publicação).

TAVARES, V. C.; ARRUDA, I. R. P.; SILVA, D. G. Desertificação, mudanças climáticas e secas no semiárido brasileiro: uma revisão bibliográfica. Geosul, v. 34, n. 70, p. 385-405, 2019. 
TEHRANI, E. N.; SAHOUR, H.; BOOIJ, M. J. Trend analysis of hydro-climatic variables in the north of Iran. Theoretical and applied climatology, v. 136, n. 1-2, p. 85-97, 2019.

THOMAS, J.; PRASANNAKUMAR, V. Temporal analysis of rainfall (1871-2012) and drought characteristics over a tropical monsoon-dominated State (Kerala) of India. Journal of Hydrology, v. 534, p. 266-280, 2016.

THORNTHWAITE, C. W.; MATHER, J. R. The water balance. Publications in Climatology, New Jersey: Drexel Institute of Technology, 1955. 104p.

TOSUNOGLU, F.; KISI, O. Trend analysis of maximum hydrologic drought variables using Mann-Kendall and Şen's innovative trend method. River Research and Applications, v. 33, n. 4, p. 597-610, 2017.

WANG, X. L. Accounting for autocorrelation in detecting mean-shifts in climate data series using the penalised maximal $\mathrm{t}$ or $\mathrm{F}$ test. Journal of applied meteorology and climatology, v. 47, n. 09, p. 2423-2444, 2008a.

WANG, X. L. Penalised maximal F-test for detecting undocumented mean shifts without trendchange. Journal of Atmospheric and Oceanic Technology, v. 25, n. 03, p. 368-384, 2008 b.

WANG, X. J.; ZHANG, J. Y.; SHAHID, S.; GUAN, E. H.; WU, Y. X.; GAO, J.; HE, R. M. Adaptation to climate change impacts on water demand. Mitigation and Adaptation Strategies for Global Change, v. 21, n. 1, p. 81-99, 2016.

WANG, Z.; YE, A.; WANG, L.; LIU, K.; CHENG, L. Spatial and temporal characteristics of reference evapotranspiration and its climatic driving factors over China from 1979-2015. Agricultural Water Management, v. 213, p. 1096-1108, 2019.

WANG, Y.; XU, Y.; TABARI, H.; WANG, J.; WANG, Q.; SONG, S.; HU, Z. Innovative trend analysis of annual and seasonal rainfall in the Yangtze River Delta, eastern China. Atmospheric Research, v. 231, p. 104673, 2020.

WU, H.; QIAN, H. Innovative trend analysis of annual and seasonal rainfall and extreme values in Shaanxi, China, since the 1950s. International Journal of Climatology, v. 37, n. 5, p. 2582-2592, 2017.

ZHOU, Z.; WANG, L.; LIN, A.; ZHANG, M.; NIU, Z. Innovative trend analysis of solar radiation in China during 1962-2015. Renewable energy, v. 119, p. 675-689, 2018.

Trabalho enviado em 10/09/2021

Trabalho aceito em 18/11/2021 